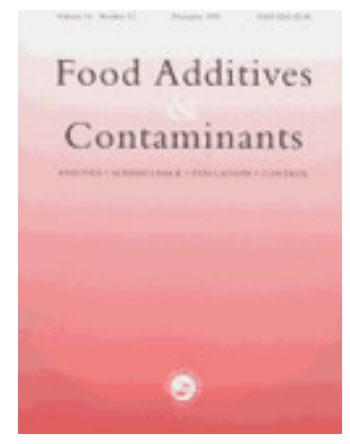

\title{
Determination of the overall migration from silicone baking moulds into simulants and food using 1H-NMR techniques
}

\begin{tabular}{|c|c|}
\hline Journal: & Food Additives and Contaminants \\
\hline Manuscript ID: & TFAC-2008-167.R1 \\
\hline Manuscript Type: & Original Research Paper \\
\hline $\begin{array}{r}\text { Date Submitted by the } \\
\text { Author: }\end{array}$ & 15-Sep-2008 \\
\hline Complete List of Authors: & $\begin{array}{l}\text { Helling, Ruediger; Landesuntersuchungsanstalt für das } \\
\text { Gesundheits- und } \\
\text { Mieth, Anja; TU-Dresden, Food Chemistry } \\
\text { Altmann, Stefan; Wacker Chemie AG, Zentrale Analytik } \\
\text { Simat, Thomas; TU-Dresden, Food Chemistry }\end{array}$ \\
\hline Methods/Techniques: & Analysis - NMR, Chromatography - HPLC, Chromatography - GC \\
\hline Additives/Contaminants: & Silicone, overall migration, Food contact materials, Food simulants \\
\hline Food Types: & Bakery products \\
\hline
\end{tabular}




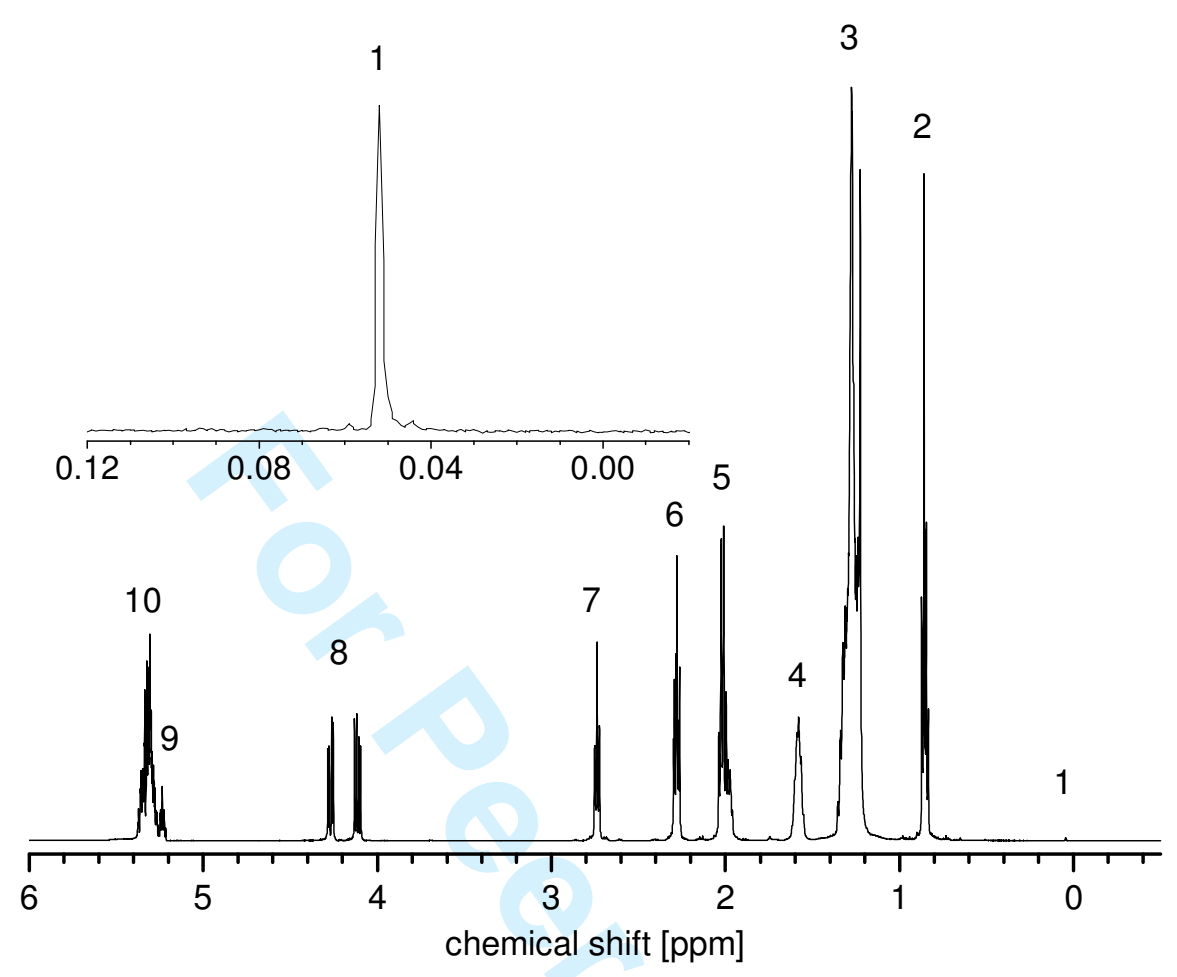

Figure 1. ${ }^{1} \mathrm{H}-\mathrm{NMR}$ spectrum of a siloxane containing fat extract. The inset shows an expanded scale for the -0.01 to $0.12 \mathrm{ppm}$ region.

1: $\delta=0.05$ ppm (s; $\left.6 \mathrm{H} ; \mathrm{Si}\left(\mathbf{C H}_{3}\right)_{2} \mathrm{O}\right), 2: 0.85 \mathrm{ppm}\left(\mathrm{m} ; 3 \mathrm{H} ; \mathrm{CH}_{3}\right.$ aliphatic), 3: 1.18-1.38 ppm (m; $2 \mathrm{H}$; $\mathbf{C H}_{2}$ aliphatic), 4: 1.54-1.62 ppm (m; $2 \mathrm{H}$; -O-CO- $\left.\mathrm{CH}_{2}-\mathrm{CH}_{2^{-}}\right)$, 5: 1.92-2.08 ppm (m; $2 \mathrm{H}$; $\left.-\mathrm{CH}_{2}-\mathrm{CH}=\right), 6: 2.29 \mathrm{ppm}\left(\mathrm{m} ; 2 \mathrm{H}\right.$; $\left.-\mathrm{O}-\mathrm{CO}-\mathrm{CH}_{2^{-}}\right), 7: 2.74 \mathrm{ppm}\left(\mathrm{m} ; 2 \mathrm{H} ;=\mathrm{CH}-\mathrm{CH}_{2}-\mathrm{CH}=\right)$, 8: 4.05-4.35 ppm (dd; $4 \mathrm{H}$; -CO-O-CH(CH$\left.\left(\mathrm{CH}_{2}-\mathrm{O}-\mathrm{CO}-\right)_{2}\right)$, 9: $5.25 \mathrm{ppm}\left(\mathrm{p}\right.$; $-\mathrm{CO}-\mathrm{O}-\mathrm{CH}\left(\mathrm{CH}_{2}-\mathrm{O}-\right.$ $\left.\mathrm{CO}-)_{2}\right), 10: 5.25-5.40 \mathrm{ppm}(\mathrm{m} ;-\mathrm{CH}=\mathrm{CH}-)$ 

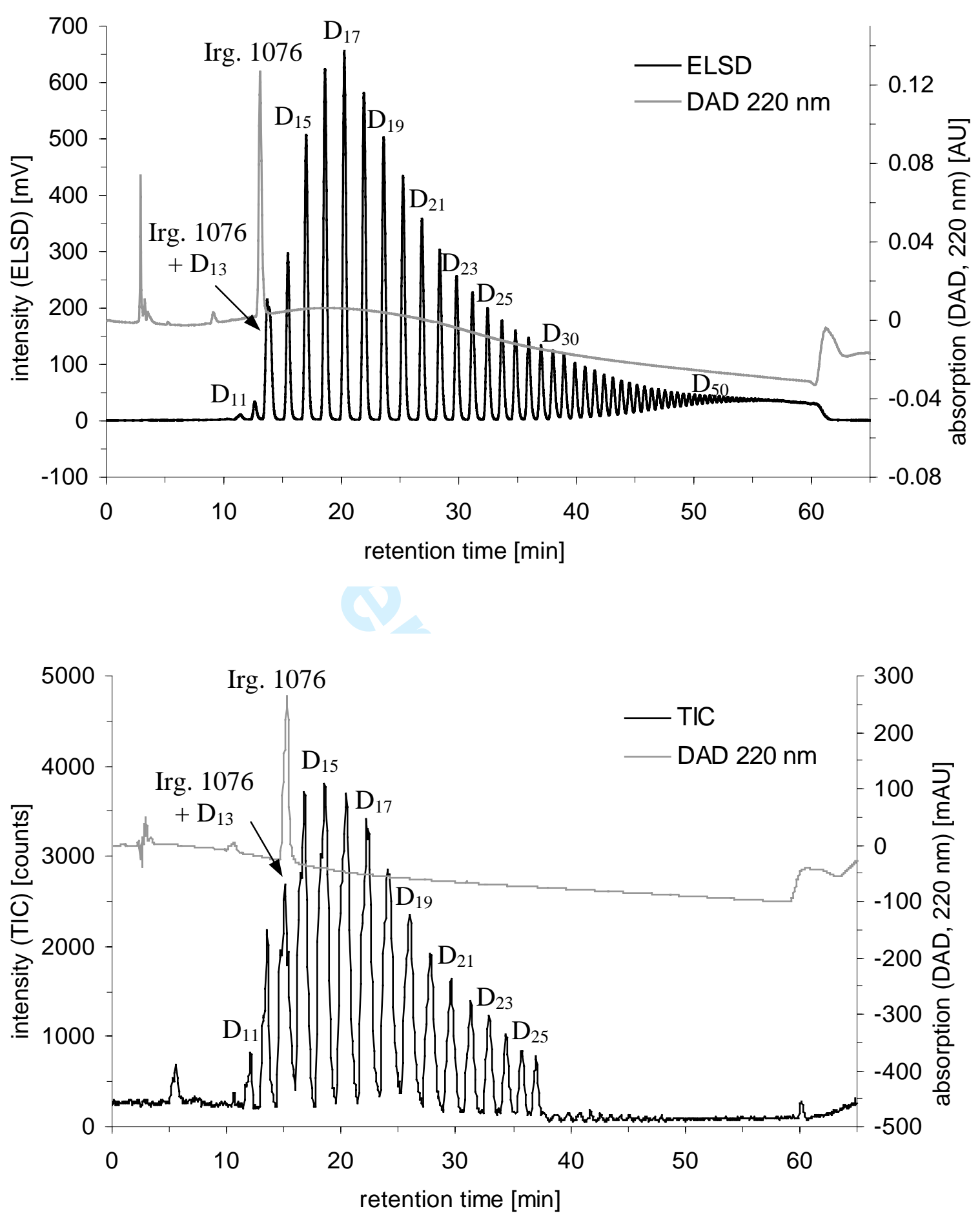

Figure 2 a) RP-HPLC-ELSD/DAD chromatogram of the migration residue;

b) RP-HPLC-MS/DAD chromatogram of the same migration residue (m/z 300-2000); Irganox 1076 was added to as an internal standard to compare both chromatograms 


\begin{tabular}{|c|c|c|c|c|}
\hline simulant & migrate & $\begin{array}{c}{ }^{1} \mathrm{H}-\mathrm{NMR} \\
\mathrm{w}_{\mathrm{A}}\left[\mathrm{mg} \mathrm{dm}^{-2}\right]\end{array}$ & $\begin{array}{c}\text { gravimetry } \\
w_{B}\left[\mathrm{mg} \mathrm{dm}^{-2}\right]\end{array}$ & $\begin{array}{r}\text { ratio } \\
\mathbf{w}_{\mathrm{A}} / \mathbf{w}_{\mathrm{H}}\end{array}$ \\
\hline \multirow[t]{3}{*}{ isooctane } & $1^{\mathrm{st}}$ & $166.7 \pm 10.6$ & $208.1 \pm 3.2$ & 0.83 \\
\hline & $2^{\text {nd }}$ & $33.3 \pm 1.2$ & $38.4 \pm 2.3$ & 0.87 \\
\hline & $3^{\text {rd }}$ & $10.7 \pm 2.9$ & $12.9 \pm 3.2$ & 0.83 \\
\hline \multirow[t]{3}{*}{ ethanol (95\%) } & $1^{\text {st }}$ & $30.2 \pm 1.4$ & $35.6 \pm 1.3$ & 0.85 \\
\hline & $2^{\text {nd }}$ & $24.7 \pm 3.1$ & $27.7 \pm 3.1$ & 0.89 \\
\hline & $3^{\text {rd }}$ & $21.1 \pm 3.9$ & $24.3 \pm 2.9$ & 0.87 \\
\hline
\end{tabular}

Table II. Overall migration into isooctane and ethanol (95\%) determined by ${ }^{1} \mathrm{H}-\mathrm{NMR}$ and gravimetry. Data shown: mean \pm confidence interval $(\alpha=0.05)$, threefold determination. 
Table V. Overall migration into creamed cake (21\% fat in the dough) from different silicone moulds, determined by ${ }^{1} \mathrm{H}-\mathrm{NMR}$. Data shown: mean (threefold determination).

\begin{tabular}{|c|c|c|c|c|c|c|}
\hline Baking dish & \multicolumn{2}{|c|}{ 12-cup muffin mould } & \multicolumn{2}{|c|}{ Loaf pan for cake } & \multicolumn{2}{|c|}{ round cake pan } \\
\hline surface/volume ratio & \multicolumn{2}{|c|}{$112 \mathrm{ml} \mathrm{dm}^{-2}$} & \multicolumn{2}{|c|}{$171 \mathrm{ml} \mathrm{dm}^{-2}$} & \multicolumn{2}{|c|}{$369 \mathrm{ml} \mathrm{dm}$} \\
\hline Baking time & \multicolumn{2}{|c|}{$25 \min$} & \multicolumn{2}{|c|}{$40 \mathrm{~min}$} & \multicolumn{2}{|c|}{$45 \mathrm{~min}$} \\
\hline Temperature & \multicolumn{2}{|c|}{$175^{\circ} \mathrm{C}$} & \multicolumn{2}{|c|}{$175^{\circ} \mathrm{C}$} & \multicolumn{2}{|c|}{$175^{\circ} \mathrm{C}$} \\
\hline Migrate & {$\left[\mathrm{mg} \mathrm{kg}^{-1}\right]$} & {$\left[\mathrm{mg} \mathrm{dm}^{-2}\right]$} & {$\left[\mathrm{mg} \mathrm{kg}^{-1}\right]$} & [mg dm $\left.\mathrm{m}^{-2}\right]$ & {$\left[\mathrm{mg} \mathrm{kg}^{-1}\right]$} & [mg dm $\left.\mathrm{m}^{-2}\right]$ \\
\hline $1^{\mathrm{st}}$ & 10.00 & 1.19 & 9.97 & 1.86 & 8.38 & 2.72 \\
\hline $3^{\text {rd }}$ & 10.11 & 1.21 & 9.96 & 1.86 & 7.99 & 2.63 \\
\hline
\end{tabular}




\title{
Determination of the overall migration from silicone baking moulds into simulants and food using ${ }^{1}$ H-NMR techniques
}

\begin{abstract}
Different silicone baking moulds (37 samples) were characterized with respect to potential migrating substances using ${ }^{1} \mathrm{H}-\mathrm{NMR}$, RP-HPLC-UV/ELSD and GC techniques. In all cases cyclic organosiloxane oligomers with the formula $\left[\mathrm{Si}\left(\mathrm{CH}_{3}\right)_{2}-\mathrm{O}\right]_{\mathrm{n}}$ were identified $(\mathrm{n}=6 \ldots 50)$. Additionally, linear, partly hydroxyl-terminated organosiloxanes $\mathrm{HO}-\left[\mathrm{Si}\left(\mathrm{CH}_{3}\right)_{2}-\mathrm{O}\right]_{\mathrm{n}}-\mathrm{H}(\mathrm{n}=$ 7...20) were found in 13 samples. No other substances than siloxanes could be detected, meaning the migrants mainly consist of organopolysiloxanes. Based on this knowledge, a ${ }^{1}$ H-NMR quantification method for siloxanes was established for the analysis of both simulants and foodstuffs. Validation of the ${ }^{1} \mathrm{H}-\mathrm{NMR}$ method gave a suitable performance characteristics: limit of detection $8.7 \mathrm{mg} \mathrm{kg}^{-1}$ oil, coefficient of variation $7.8 \%$ (at a level of $1.0 \mathrm{mg} \mathrm{kg}^{-1}$ food). Migration studies were carried out with simulants (olive oil, isooctane, ethanol (95\%), Tenax) as well as preparation of different cakes. Siloxane migration into cakes only slightly decreased in going from the $1^{\text {st }}$ to $10^{\text {th }}$ experiment with a significant dependence on fat content. Migration never exceeded a level of $21 \mathrm{mg} \mathrm{kg}^{-1}\left(3 \mathrm{mg} \mathrm{dm}^{-2}\right)$ and thus migration was therefore well below the overall migration limit of $60 \mathrm{mg} \mathrm{kg}^{-1}$ (10 mg dm ${ }^{2}$ ). However, migration behaviour into simulants differed completely from these results.
\end{abstract}

Keywords: Silicones, polydimethylsiloxanes, ${ }^{1} \mathrm{H}-\mathrm{NMR}$, migration, foodstuffs, cake 


\section{Introduction}

Silicone elastomers are widely used as food contact materials. Because of their non-sticking properties, high temperature resistance and flexible form, their use as baking moulds and pads is very common. Their market share among baking moulds within the last few years was in a range between $23 \%$ and $46 \%$ (GFK Panel Services Germany).

There are only few publications describing the migration behaviour of silicone elastomers in contact with foodstuffs or food simulants. High overall migration from silicone elastomers was reported for foodstuffs containing free available fat (Forrest and Sidwell 2005, RAPEX 2007). As to be expected, no notable migration into aqueous or acidic simulants was described so far. Meuwly et al. (2005) investigated the overall migration from different silicone baking moulds into modified polyphenylene oxide (Tenax) and obtained values well above the overall migration limit of $10 \mathrm{mg} / \mathrm{dm}^{2}$, for the $1^{\text {st }}$ as well as for the $3^{\text {rd }}$ migration experiment. Increasing temperatures caused higher migration values, the highest amount reported being $50.5 \mathrm{mg} \mathrm{dm}^{-2}$. Characterisation of the migrate was carried out using GC-MS and MALDI-TOF and showed cyclic and linear polydimethylsiloxanes up to a molecular weight of $1500 \mathrm{Da}$ as the only components.

Until 2001 silicone elastomers were covered by the Plastics Directive 90/128/EC and had to conform to the overall migration limit of $60 \mathrm{mg} \mathrm{kg}^{-1}\left(10 \mathrm{mg} \mathrm{dm}^{-2}\right)$. With Commission Directive 2001/62/EC, silicone elastomers were excluded from the plastics definition because of their physical properties, which are more similar to elastomers than to other plastics like polyolefins. Still no specific European legislation exists concerning silicone elastomers intended to come into contact with foodstuffs. This gap is filled by the Council of Europe's Resolution AP (2004) 5 on silicones used for food contact applications as well as the recommendation $\mathrm{XV}$ on silicone articles, set up by the Federal Institute for Risk Assessment (BfR), Germany (BfR 2007). The Resolution AP (2004) 5 limits the overall migration to 60 $\mathrm{mg} \mathrm{kg}^{-1}$ food $\left(10 \mathrm{mg} \mathrm{dm}^{-2}\right)$, whereas in the German recommendation XV limits for the loss of volatile organic compounds and extractable compounds are set up, each to 0,5 g/100 g silicone elastomer. Although the Resolution AP (2004) 5 has only a status of recommendation in most European countries, some introduced it into national legislation. So did the Swiss authorities last in December 2006 (Swiss EDI 2005). 
In consequence, the Rapid Alert System for Food and Feed (RASFF) of the European Commission shows notifications from EU member states who want to alert control authorities of silicone articles because of a too high overall migration in the olive oil migration test as well as the response of other countries (e.g. Germany) who declare such articles as conforming to national law (RAPEX 2006). Most notifications are on silicone materials exceeding the limit for volatile organic compounds, although it is not proven how far the amount of migration into food depends on the amount of volatile compounds.

In the field of food contact materials made of plastics, the Council Directives 85/572/EEC, 82/711/EEC and Commission Directive 2002/72/EC define how to perform migration experiments and which food types and simulants should be used. Baking moulds which are used for making pastries containing free available fat should be tested with olive oil. Isooctane, ethanol (95\%) and Tenax are allowed as alternative simulants if the use of olive oil is impossible for technical reasons. As required for repeat-use articles, only the result of the $3^{\text {rd }}$ migration experiment is of legal relevance (Commission Directive 2002/72/EC).

Silicone elastomers are not covered by these Directives, so the test procedures described here are not compulsory. On the other hand Resolution AP (2004) 5 declares, that migration tests should be conducted according to these Directives as appropriate, unless technically impracticable due to the nature of the material or the migration tests. Such a case of technical impracticability was stated for the migration test using olive oil. According to the Federal Institute for Risk Assessment (BfR), olive oil is not suitable for silicones due to the swelling of the material (BfR 2006). For that reason, most laboratories use Tenax ${ }^{\circledR}$ for migration experiments despite some others using ethanol (95\%), but there is a big uncertainty concerning the interpretation and legal status of these data. Furthermore, there are differences concerning the use of a fat reduction factor as described in Council Directive 85/572/EEC. To clarify this, a comparison of all the fatty food simulants and some real foodstuffs is needed.

Until now, no validated method was published allowing the determination of the overall migration from silicone elastomers into fatty foodstuffs. Hence, there was no possibility to prove the criteria of the Resolution AP (2004) 5 in foodstuffs. Furthermore, such a method would be of great importance to assess the suitability of migration tests with olive oil or simulants for silicone elastomers by comparing these results with the amounts measured in 
food. Therefore, a validated and generally accepted method for the determination of the overall migration from silicone elastomers into foodstuffs is needed.

Some analytical techniques allow the determination of siloxanes in foodstuffs. Atomic spectroscopic methods (AAS/AES, ICP-MS, ICP-OES) are most widely used (Čavić-Vlasak et al. 1996, Mccamey et al. 1986, Peters et al. 1995, Kennan et al. 1999, Dorn and Skelly 1994, Biggs et al. 1987). These methods are very specific for silicon but they do not allow one to distinguish between organic and inorganic bound silicon. It is impossible to determine only the content of polydimethylsiloxanes (PDMS) as an extent of migration from silicone elastomers. Several methods based on AAS and ICP-AES techniques for PDMS determination in food after extraction with chloroform or other solvents have been described, with a recoveries from 90-95\% and precision of the determination between 1 and $6 \%$ (ČavićVlasak et al. 1996, Mojsiewicz-Pieńkowska et al. 2003). The main drawbacks are possible interferences with inorganic bound silicon and the potential loss of siloxanes with low molecular mass before atomization. A useful, but quite expensive alternative might be the use of HPLC-ICP-AES. This technique would offer the possibility to separate organic and inorganic bound silicon first by liquid chromatography before quantification with ICP-AES. Infrared spectroscopic methods are specific for organosiloxanes but are little sensitive and need massive sample enrichment. Direct analyses in the lower $\mathrm{mg} \mathrm{kg}^{-1}$ range are not feasible (Čavić-Vlasak et al. 1996). The crux is to separate the siloxanes from the big excess of fat in the food extracts which has an almost similar polarity. The main difficulty of chromatographic methods is the lack of analytical references for cyclic siloxanes in the mid and high molecular range which are essential for a reliable quantification.

For all this reasons, we decided to use ${ }^{1} \mathrm{H}-\mathrm{NMR}$ techniques for quantification. MojsiewiczPieńkowska et al. (2003) described a method to quantify linear polydimethylsiloxanes (food additive E 900) in edible oils after saponification and extraction with tetra chloromethane. The limit of reliable detection was $3 \mathrm{mg} \mathrm{l}^{-1}$ which is well below the expected range for migrating siloxanes from silicone moulds. The advantage of ${ }^{1} \mathrm{H}-\mathrm{NMR}$ quantification is the specific and isolated singlet signal for the $\left[-\mathrm{Si}\left(\mathrm{CH}_{3}\right)_{2}-\mathrm{O}-\right]_{\mathrm{n}}$-group in linear and cyclic siloxanes. Furthermore, even the protons of cyclic oligomers of different size are mainly chemically equivalent, resulting in only one signal for all the oligomers and thus increasing sensitivity. No analytical reference is needed. The highly specific signal for all cyclic siloxanes should also allow a direct measurement, even without prior saponification of the fat. 


\section{Materials and methods}

\section{Silicone moulds}

The characterized silicone moulds were from various manufacturers and were all bought on the German market. More detailed investigations concerning the relation between different simulants as well as food preparation experiments were carried out with a commercial 12 cups muffin silicone mould (volume: $95.8 \mathrm{~cm}^{3}$, contact area: $0.86 \mathrm{dm}^{2}$, thickness: $1.0 \mathrm{~mm}, \mathrm{Pt}$ catalyzed cross-linked) bought on the German market, too. Single cups were cut from this sample and used for the migration tests.

All samples were first washed with warm water $\left(45-50^{\circ} \mathrm{C}\right)$ and washing-up liquid, as recommended by the manufacturers.

\section{Chemicals}

Olive oil was purchased from Fluka Germany, Tenax ${ }^{\circledR}$ (modified polyphenylene oxide, MPPO) from Alltech Germany. Any other chemicals were obtained from Sigma-Aldrich Germany at analytical grade or higher. All food ingredients, used for the baking studies, were of commercial quality.

\section{Silicone samples}

In total 37 different silicone moulds were examined: 2 muffin pans with 15 cups, 4 muffin pans with 12 cups, 7 muffin pans with 6 cups, 7 bundform pans ('Gugelhupf'), 5 loaf pans, 3 round cake pans, 2 mini cake moulds for 12 pieces "Madeleine" and 7 motive moulds (Disney characters, Christmas tree, teddy bear). The thickness of all moulds was in the range of 1-2 
$\mathrm{mm}$, maximum temperature as given by the manufacturer was from $220^{\circ} \mathrm{C}$ to $260{ }^{\circ} \mathrm{C}$. Most of the moulds were blue coloured except three red moulds shaped like Disney characters.

\section{Migration into food simulants}

Olive oil, isooctane, 95\% ethanol and modified polyphenylene oxide (MPPO, Tenax®) were used as test media. The test conditions were based on common time-and-temperature conditions used for baking muffins and were selected according to Council Directive 82/711/EEC chapter $3 \mathrm{~N}^{\circ} 1$ and table 4 . As baking moulds are intended for repeated usage, the first, second and third overall migrate were determined in all cases (Commission Directive 2002/72/EC).

\section{Migration into olive oil}

The tests were carried out as described in part 8 of the European Standard EN 1186:2002 and Commission Directive 2002/72/EC attachment $1 \mathrm{~N}^{\mathrm{o}} 6$ with the following modifications: The samples were filled to the brim with a pre-heated amount of olive oil $\left(90 \mathrm{ml}, 175^{\circ} \mathrm{C}\right)$ and then placed in a pre-heated oven at $175^{\circ} \mathrm{C}$. As a blank sample, an equivalent amount of olive oil was poured into a flask and then treated identically. Time measurement was already started when the samples were put into the oven, although the examination temperature of $175^{\circ} \mathrm{C}$ was regained later. Contrary to repeating the migration experiment three times with one mould for $25 \mathrm{~min}$ at $175{ }^{\circ} \mathrm{C}$, a different approach according to Commission Directive 2002/72/EC (Annex I No. 6) was chosen. Three moulds were incubated with olive oil at $175^{\circ} \mathrm{C}$ for 25,50 (mimicking $1^{\text {st }}$ and $2^{\text {nd }}$ migration) and $75 \min$ (mimicking $1^{\text {st }}, 2^{\text {nd }}$ and $3^{\text {rd }}$ migration), respectively. Quantification of olive oil in the extracts of the silicone moulds was carried out by determination of the triglycerides using normal phase HPLC and evaporative light scattering (ELS) detection. Analysis were performed on a Merck HPLC-DAD 7000 coupled with an ELS-detector Sedex 75 (Sedere, Alfortville, France) with the following parameters: chromatographic column: LiChrospher 100 Diol-5 $\mu, 125$ x 3 mm (Merck, Darmstadt, Germany), isocratic elution: 2-methoxy-2-methyl-propane/isooctane 4/96 (v/v), run time: 12 min, flow: $0.5 \mathrm{ml} \mathrm{min}{ }^{-1}$, injection volume: $20 \mu \mathrm{l}$, column temperature: $25^{\circ} \mathrm{C}$, nebulization temperature: $20^{\circ} \mathrm{C}$, evaporation temperature: $35^{\circ} \mathrm{C}, \mathrm{N}_{2} 3.5$ bar, gain: 8 , calibration: olive oil dissolved in isooctane. The triglyceride peak showed a retention time of about $5 \mathrm{~min}$. 


\section{Migration into isooctane and 95\% ethanol}

The tests were carried out as a threefold determination as described in part 14 of the European Standard EN 1186:2002 with the following modifications: To determine the overall migration into isooctane, the samples were cut into stripes of $3 \mathrm{~cm} \times 5 \mathrm{~cm}$, put into $180 \mathrm{ml}$ of the preheated solvent and then placed in a pre-heated oven at $60^{\circ} \mathrm{C}$. For migration tests with ethanol/water $95 / 5(\mathrm{v} / \mathrm{v})$, the intact samples were filled to the brim with the pre-heated solvent $\left(90 \mathrm{ml}, 60^{\circ} \mathrm{C}\right)$. In both cases, only the inside surface area of the moulds was assumed as contact area, although during the isooctane migration the whole surface (inside and outside area) of the moulds was in contact with the simulant. Isooctane leads to an extensive, but even swelling of the complete silicone moulds, also during one-side contact. So it has to be supposed that substances may be able to migrate from the outer to the inner side of the baking moulds, resulting in nearly the same results as to be expected for a two-sided migration. A similar effect is well known e.g. for plasticizers in thin PVC-films (Kim 2003). Again, time measurement was already started when the samples were put into the oven, although the examination temperature of $60^{\circ} \mathrm{C}$ was regained later. An exposure time of $50 \mathrm{~min}$ for isooctane and $75 \mathrm{~min}$ for $95 \%$ ethanol was chosen, respectively. The used solvent was refilled to a defined volume (100 or $200 \mathrm{ml}$ ) and divided into two portions. About 2/3 of the solvent were used to determine the overall migration by the gravimetric standard method. The remaining part was concentrated by evaporation (rotary evaporator) and refilled to $5 \mathrm{ml}$ with simulant solvent. 100-200 $\mu$ l of this solution were mixed with $0.5-2 \mathrm{~g}( \pm 0.1 \mathrm{mg})$ of sunflower oil, resulting in a mixture containing about $150-400 \mathrm{mg}$ siloxane per $\mathrm{kg}$ sunflower oil. For ${ }^{1} \mathrm{H}-$ NMR analysis, $200 \mathrm{mg}$ of this mixture were dissolved in $800 \mu \mathrm{l} \mathrm{CDCl}_{3}$, filtered and transferred into a NMR-tube. The ${ }^{1} \mathrm{H}-\mathrm{NMR}$ signals of the simulant solvents, isooctane and ethanol, do not disturb the analysis of the siloxane and triglyceride signal.

\section{Migration into Tenax ${ }^{\circledR}(M P P O)$}

The tests were carried out as described in part 13 of the European Standard EN 1186:2002. For a threefold determination three flat pieces, each with an area of about $15 \mathrm{~cm}^{2}$, were cut from the bottom of the baking moulds. The samples were put into a Petri dish and covered with $0.6 \mathrm{~g}$ Tenax ${ }^{\circledR}\left(4 \mathrm{~g}\right.$ Tenax $\left.{ }^{\circledR} / 1 \mathrm{dm}^{2}\right)$. The Petri dish was closed and then put into the preheated oven at $175^{\circ} \mathrm{C}$. As a blank sample, Tenax ${ }^{\circledR}$ was filled into a Petri dish without sample material. 
Time measurement started when the examination temperature of $175^{\circ} \mathrm{C}$ was regained, exposure time was $25 \mathrm{~min}$. Gravimetrical determination of the migration residue followed the procedure described in EN 1186:2002 part 13.

\section{Qualitative analyses of the migration residue (overall migration into isooctane)}

For liquid chromatography, an Agilent 1100 G HPLC-DAD (Hewlett Packard, Palo Alto, CA) coupled with an ESI-TOF-MS-detector (Biospectrometry Workstation; Applied Biosystems, Foster City, CA) and a Merck HPLC-DAD 7000 (Merck, Darmstadt, Germany) coupled with an ELS-detector Sedex 75 (Sedere, Alfortville, France) were used. Irganox 1076 (octadecyl-3(3‘,5'-di(tert-butyl)-4'hydroxyphenyl)propanoate, CAS No. 2082-79-3) was added to the sample solution as a retention time standard to allow the assignment of the peaks observable in the HPLC-MS and HPLC-ELSD chromatograms. The amount of Irganox 1076 in the sample solution was about $200 \mathrm{mg} \mathrm{l}^{-1}$.

The measurement parameters were as follows:

chromatographic column: Multospher 120 RP 18 HP 5 m 250 x 3 mm (CS-Chromatography Service), gradient elution: isopropanol(A)/methanol(B), starting with $10 \%$ isopropanol and reaching 85\% within $55 \mathrm{~min}$, flow: $0.5 \mathrm{ml} \mathrm{min}^{-1}$, injection volume: $10 \mu 1$ (HPLC-DAD/ELSD) or $25 \mu \mathrm{l}$ (HPLC-DAD/MS), column temperature: $40^{\circ} \mathrm{C}$, ELSD parameters: nebulization temperature: $25^{\circ} \mathrm{C}$, evaporation temperature: $30^{\circ} \mathrm{C}, \mathrm{N}_{2} 3$ bar, gain: 8 , UV: $220 \mathrm{~nm}$.

Gas chromatography was done on a Hewlett-Packard 6890 GC (Hewlett Packard, Palo Alto, CA) equipped with a 5973 mass selective detector. A HP-5MS capillary column $(30 \mathrm{~m}, 0.25$ $\mathrm{mm}$ ) was used. The MS detector was operated in full scan mode, scan range $\mathrm{m} / \mathrm{z} 70-800$. Diallylphthalate $(\mathrm{c}=5 \mathrm{mg} / \mathrm{l})$ served as an internal standard.

Quantification experiments were performed on a Hewlett-Packard 5890 GC with flame ionization detector (FID), again using a HP-5MS capillary column (30 m, $0.25 \mathrm{~mm})$. Injection was splitless using a split/splitless injection system at $280^{\circ} \mathrm{C}$. High temperature GC was done at an injection temperature of $330^{\circ} \mathrm{C}$, expanding the oven program to $430^{\circ} \mathrm{C}$ and using a high temperature GC column of adequate polarity (Phenomenex ZB-5HT Inferno, $30 \mathrm{~m}, 0.25 \mathrm{~mm}$, Phenomenex, Torrance, CA). Increasing the injector temperature up to $350^{\circ} \mathrm{C}$ resulted in a high septum bleeding but unimproved peak shape or response. 


\section{Elemental analysis}

Elemental analysis was performed using a EuroVector EA 3000 (HEKAtech, Wegberg, Germany).

\section{Migration into foodstuffs}

The baking studies were performed with two different kinds of creamed cake.

Creamed cake, $21 \%$ total fat (Das Backbuch, 1967)

The dough contained $125 \mathrm{~g}$ sunflower oil, $100 \mathrm{~g}$ egg (homogenized), $125 \mathrm{~g}$ sugar, $250 \mathrm{~g}$ wheat flour, $8 \mathrm{~g}$ baking powder and $50 \mathrm{~g}$ water.

Creamed cake, 30 \% total fat (Backen und Genießen 1999)

The dough consisted of $200 \mathrm{~g}$ sunflower oil, $200 \mathrm{~g}$ egg (homogenized), $150 \mathrm{~g}$ sugar, $200 \mathrm{~g}$ wheat flour and $8 \mathrm{~g}$ baking powder.

\section{Baking procedure}

The samples were filled to the brim with dough and then put into the pre-heated oven at $175^{\circ} \mathrm{C}$. After a suitable baking time ( $25 \mathrm{~min}$ for muffins, $40 \mathrm{~min}$ for creamed cake in a loaf pan, $45 \mathrm{~min}$ for creamed cake in a round cake pan), the samples were removed from the oven. The cakes were removed from the moulds and each one was put into a beaker.

For the blank samples, the dough was filled into a Teflon coated metal baking mould.

\section{Soxhlet extraction}

The cakes were homogenized and an equivalent (approx. $12 \mathrm{~g}$ of the cake) was mixed with sodium sulphate $\left(\mathrm{Na}_{2} \mathrm{SO}_{4}\right)$ (approx. $15 \mathrm{~g}$ ) thoroughly in a mortar.

The dry powder was transferred quantitatively into a Soxhlet cartridge and extracted for $4 \mathrm{~h}$ with $150 \mathrm{ml}$ diethyl ether in a Soxhlet extractor to isolate the fat matrix, including the siloxanes. At the end of the extraction, the diethyl ether was removed from the roundbottomed flask by distillation. Before and after extraction, the flask was dried repeatedly for $1 \mathrm{~h}$ at $103^{\circ} \mathrm{C}$ until constant weight was reached. The weight of the lipid extract was determined accurate to $0.1 \mathrm{mg}$.

Sodium sulphate had to be annealed for $3 \mathrm{~h}$ at $550{ }^{\circ} \mathrm{C}$ in a muffle furnace prior to use to remove siloxane impurities lasting from manufacturing. Soxhlet cartridges and filter papers used to clean the mortar and pestle were extracted thoroughly in a Soxhlet extractor with diethyl ether prior to use.

\section{NMR measurement}


For NMR measurement $400 \mathrm{mg}$ of the extracted fat were dissolved in $800 \mu \mathrm{CDCl}_{3}$, filtered through silicone free paper and transferred into a NMR tube. The ${ }^{1} \mathrm{H}-\mathrm{NMR}$ spectra were recorded at $500 \mathrm{MHz}$ on a DRX $500 \mathrm{P}$ NMR spectrometer (Bruker). Parameter settings were as follows: temperature: $22^{\circ} \mathrm{C}$, number of scans: 128 , spectral width: $10330 \mathrm{~Hz}$, acquisition time: $3.17 \mathrm{~s}$, resolution: $0.158 \mathrm{~Hz}$ per point, frequency sample rotation: $20 \mathrm{~Hz}$, pulse delay: 1 s, pulse angle: $30^{\circ}$. Tetramethylsilane (TMS) was not added as a position standard for the chemical shift. Instead of this, the solvent signal $\left(\delta\left(\mathrm{CHCl}_{3}\right)=7.25 \mathrm{ppm}\right.$ in relation to TMS $)$ was used to ascertain the position of resonance bands.

\section{Calculation of the siloxane content}

The extracted fat mainly consists of triglycerides. They serve as internal standard for quantification. They form a distinct double doublet (dd) resonance signal in a range of $\delta=$ 3.95-4.45 ppm (including ${ }^{13} \mathrm{C}$ satellites). For quantification, the whole double doublet signal is integrated within this range. The signal is caused by the four protons at $\mathrm{C} 1$ and $\mathrm{C} 3$ of the triglyceride backbone. The cyclic dimethylsiloxanes represent the main part of the overall migrate giving a sharp singlet at $0.05 \mathrm{ppm}$, which is formed by the six equivalent protons per $\left[-\mathrm{Si}\left(\mathrm{CH}_{3}\right)_{2}-\mathrm{O}-\right]$ unit.

"[Insert Figure 1 about here]"

Terminal siloxane units in linear hydroxyl terminated siloxanes give a signal at $0.16 \mathrm{ppm}$ $\left(\mathrm{HO}-\mathrm{Si}\left(\mathrm{CH}_{3}\right)_{2} \mathrm{O}-\right)$ and $0.11 \mathrm{ppm}\left(\mathrm{HO}-\mathrm{Si}\left(\mathrm{CH}_{3}\right)_{2} \mathrm{O}-\mathrm{Si}\left(\mathrm{CH}_{3}\right)_{2} \mathrm{O}-\right)$. Terminal groups in linear trimethylsilyl terminated siloxanes give a signal at $0.08 \mathrm{ppm}\left(\mathrm{Si}\left(\mathrm{CH}_{3}\right)_{3} \mathrm{O}_{-}\right)$and $0.03 \mathrm{ppm}$ $\left(\mathrm{Si}\left(\mathrm{CH}_{3}\right)_{3} \mathrm{O}-\mathrm{Si}\left(\mathrm{CH}_{3}\right)_{2} \mathrm{O}-\right)$. Their influence on the chemical shift of other methyl protons is limited to neighbouring groups, so that most methyl protons in linear siloxanes give a signal (as do cyclic siloxanes) at approximately $0.05 \mathrm{ppm}$. The amount of siloxane was calculated from the sum of all siloxane integrals in the spectrum. By approximation, the result can be expressed in $\left[\mathrm{Si}\left(\mathrm{CH}_{3}\right)_{2} \mathrm{O}\right]$-groups, which corresponds to a cyclic siloxane. Using this method of calculation, the molar mass of linear siloxanes, and therefore also the siloxane amount, is slightly underestimated for hydroxyl terminated molecules (18 Da) and overestimated for trimethylsilyl terminated ones (30 Da). The resulting error can be disregarded, knowing that the migrating linear siloxanes range between 700 and well above 2000 Da. 
A calibration was established using decamethylcyclopentasiloxane $\left(D_{5}\right)$ in sunflower oil. Linearity was confirmed $\left(r^{2}\right.$ 0.9975) between the amount of siloxanes per kilogram triglyceride (abscissa) and the quotient of the integrals of the siloxane and triglyceride signals (ordinate).

The overall migrate can be calculated as follows (without use of the calibration mentioned above):

$$
\mathrm{w}_{\mathrm{m}}=\frac{\mathrm{I}_{\mathrm{sil}} \cdot \mathrm{M}_{\text {sil }} \cdot \mathrm{p}_{\mathrm{TG}} \cdot \mathrm{m}_{\mathrm{fat}}}{\mathrm{I}_{\mathrm{TG}} \cdot \mathrm{M}_{\mathrm{TG}} \cdot \mathrm{p}_{\mathrm{sil}} \cdot \mathrm{m}_{\mathrm{equ}}}
$$

where $\mathrm{w}_{\mathrm{m}}$ is the overall migrate $\left[\mathrm{mg} \mathrm{kg}^{-1}\right.$ food], $\mathrm{I}_{\mathrm{sil}}$ and $\mathrm{I}_{\mathrm{TG}}$ are the integrals of the siloxane and the triglyceride signal, $\mathrm{M}_{\mathrm{sil}}$ is the molar mass of the $\left[-\mathrm{Si}\left(\mathrm{CH}_{3}\right)_{2}-\mathrm{O}-\right]$ unit $\left[\mathrm{g} \mathrm{mol}^{-1}\right]\left(\mathrm{M}_{\mathrm{sil}}=\right.$ $\left.74,2 \mathrm{~g} \mathrm{~mol}^{-1}\right)$, and $\mathrm{M}_{\mathrm{TG}}$ is the average molar mass of the triglycerides [ $\mathrm{g} \mathrm{mol}^{-1}$ ] $\left(\mathrm{M}_{\mathrm{TG}}\right.$ was calculated from the ${ }^{1} \mathrm{H}-\mathrm{NMR}$ spectrum of the lipid matrix as described below), $\mathrm{p}_{\text {sil }}$ and $\mathrm{p}_{\mathrm{TG}}$ are the number of protons responsible for the resonance signal of interest $\left(\mathrm{p}_{\mathrm{sil}}=6, \mathrm{p}_{\mathrm{TG}}=4\right), \mathrm{m}_{\text {equ }}$ is the mass of the food equivalent $[\mathrm{kg}]$, which was used for Soxhlet extraction, $\mathrm{m}_{\mathrm{fat}}$ is the mass of fat [mg], which was extracted from the food equivalent.

Calculation of the surface related migration:

$$
\mathrm{w}_{\mathrm{a}}=\mathrm{w}_{\mathrm{m}} \cdot \frac{\mathrm{m}_{\text {food }}}{\mathrm{A}_{\mathrm{O}}}
$$

where $\mathrm{w}_{\mathrm{a}}$ is the overall migrate $\left[\mathrm{mg} \mathrm{dm}^{-2}\right.$ contact area], $\mathrm{m}_{\text {food }}$ is the mass of food, which was prepared in the tested silicone mould and $A_{O}$ is the contact area $\left[\mathrm{dm}^{2}\right]$ between the baking mould and the foodstuff during baking.

Determination of $\mathrm{M}_{\mathrm{TG}}$ from the ${ }^{1} \mathrm{H}-\mathrm{NMR}$ spectrum of the lipid matrix:

All signals of the lipid matrix are integrated (see figure 1, signal 2-10), integrals of similar subunits of the triglyceride molecule are summed up. Signals 8 and 9 are not fully separated, so they are integrated as one signal for $\mathrm{CH}$-groups. The carboxy group at $\mathrm{C} 2$ of the triglyceride backbone is then regarded separately in the calculation (see table I).

"[Insert table I about here]" 
So the average molar mass of triglycerides in the used sunflower oil is:

$$
\mathrm{M}_{\mathrm{TG}}=\sum\left(\mathrm{M}_{\mathrm{SU}} \cdot \frac{\left(\mathrm{I} \cdot \mathrm{p}^{-1}\right)_{\mathrm{SU}}}{\left(\mathrm{I} \cdot \mathrm{p}^{-1}\right)_{\mathrm{TB}}} \cdot 2\right)=\underline{\underline{872,58 \frac{\mathrm{g}}{\mathrm{mol}}}}
$$

\section{Determination of the recovery rate of cyclic siloxanes in muffins}

A baking study with a creamed cake (21\% fat) was carried out using siloxane spiked sunflower oil. As there were only low molecular, volatile cyclic siloxane compounds commercially available, spiking of the sunflower oil was done indirectly. Exactly, the sunflower oil was used to perform an overall migration experiment with a silicone baking mould for 25 min (see "migration into olive oil"). After this, the siloxane amount in the sunflower oil was determined by ${ }^{1} \mathrm{H}-\mathrm{NMR}$ measurement (see "NMR measurement"). The sunflower oil containing the determined amount of siloxanes was then used as ingredient for a creamed cake ( $21 \%$ fat). The baking study was performed as described in "migration into foodstuffs", using a Teflon ${ }^{\circledR}$ coated metal baking mould. The siloxane content was determined again by NMR in the dried fat extract.

\section{Results and discussion}

\section{Characterization of the migration residue}

Thirty-seven different baking moulds were characterized with respect to potential migrating substances. Ethanol (95\%) or isooctane extracts were all analysed using RP-HPLC with UV and light scattering detection; most of the extracts were analysed by GC-MS and GC-FID, too. To compare the chromatograms of both liquid chromatography techniques Irganox 1076 (octadecyl-3-(3‘,5'-di(tert-butyl)-4'hydroxyphenyl)propanoate, CAS No. 2082-79-3) was used as an internal standard. Fig. 2 shows two typical corresponding chromatograms of an isooctane migration residue of a muffin mould. Cyclic oligomers below 13 siloxane units are discriminated in light scattering detection due to their relatively high volatility and are better to detect with MS techniques.

“[Insert Figure 2 about here]"

In all cases cyclic organosiloxane oligomers with the formula $\left[-\mathrm{Si}\left(\mathrm{CH}_{3}\right)_{2}-\mathrm{O}-\right]_{\mathrm{n}}$ have been identified $(n=6 \ldots 50)$. Additionally, linear organosiloxanes $(n=7 \ldots 20)$ have been detected in the extracts of 13 moulds in a lower concentration (Fig. 3). This is in accordance with the 
migrating substances described by Meuwly et al. (2005). No other substances than siloxanes could be observed in a comparable concentration range, meaning the migrants mainly consist of organopolysiloxanes and no other substances should play an important role in the determination of the overall migration.

“[Insert Figure 3 about here]"

GC-chromatograms indicated the presence of low molecular weight siloxanes only in some moulds in minor concentrations, whereas cyclic siloxanes up from 14 monomer units were detected in all moulds investigated. Oligomers with more than 30 [- $\mathrm{Si}\left(\mathrm{CH}_{3}\right)_{2}-\mathrm{O}$-]-units are little volatile and hardly to be seen by GC limiting the applicability of this technique for quantification of the migration residue (Fig. 4).

\section{"[Insert Figure 4 about here]"}

To estimate the part of the overall migration which is accessible by GC a calibration was carried out with dodecamethylcyclohexasiloxane (D6) using a flame ionisation detector (FID) in the range of 0.5 to $80 \mathrm{mg} / \mathrm{l}$. Commercial silicone oils with a mid molecular weight of 700 Da (TMS-07) or 1100 Da (TMS-11) quantified under use of the D6 calibration curve gave a recovery rate of $91 \%$ and $49 \%$ respectively. The ethanol $(95 \%)$ migration residue of 4 different baking moulds all consisting only of cyclic siloxanes was analysed the same way resulting in recovery rates in the range of $13-20 \%$ compared to the gravimetric results. Thus, determination of the overall migration from silicone moulds by $\mathrm{GC}$ in the common temperature range up to $340^{\circ} \mathrm{C}$ is impossible due to the little volatility of the oligomers.

Further experiments performed with a high temperature GC column, an injection temperature of $360^{\circ} \mathrm{C}$ and a final oven temperature of $410^{\circ} \mathrm{C}$ resulted in a recovery rate for silicone oil TMS-11 of $93 \%$ but of only up to $56 \%$ for the ethanolic migration residue of the tested baking moulds. This can be attributed to the high molecular weight of most of the migrating cyclic siloxanes compared to TMS-11 and it limits the applicability of even high temperature GC for determination of the overall migration from silicone food contact materials.

The isooctane extract of one typical muffin mould was more detailed characterized using ${ }^{1} \mathrm{H}$ NMR and elemental analysis beside HPLC and GC. The ${ }^{1} \mathrm{H}-\mathrm{NMR}$ spectrum shows a 
dominating signal around $0.06 \mathrm{ppm}$ chemical shift for the chemical equivalent protons of the cyclic oligomers $\left[-\mathrm{Si}\left(\mathrm{CH}_{3}\right)_{2}-\mathrm{O}-\right]_{\mathrm{n}}$. Much smaller signals for the ${ }^{13} \mathrm{C}$-satellites at -0.07 and 0.18 ppm (coupling of ${ }^{1} \mathrm{H}$ - with ${ }^{13} \mathrm{C}$-nucleusses; ${ }^{1} \mathrm{~J}(\mathrm{C}, \mathrm{H})=115 \mathrm{~Hz}$ ) and rotation side signals are detected. As a result of two-dimensional HMBC-NMR, it could be shown that a somewhat broad peak at $0,13 \mathrm{ppm}$ stands for $\left(\mathrm{CH}_{3}\right)_{3} \mathrm{SiO}_{1 / 2}$-groups (M) beside quaternary (Q) silicium atoms (Fig. 5). These MQ-units are supposed to belong to so called MQ-resins which are widely used by industry as fillers (Vincent, 2000).

\section{“[Insert Figure 5 about here]"}

Such highly branched siloxane compounds, so called MQ-resins, are widely used as an additive in the production of silicone elastomers with high tensile strength.

Elemental analysis of the isooctane migration residue showed an C:H-ratio of 1:3 indicating the presence of $\mathrm{CH}_{3}$-groups. The total amount of carbon and hydrogen was $32.40 \%$ and 8.84 $\%$, respectively, lying in the expected range for cyclic dimethylsiloxanes which theoretically contain $32.4 \%$ and 8.2. No hints for any other compounds were found. Elemental analysis of the baking mould itself showed contents of $23.66 \%$ carbon and $5.87 \%$ hydrogen, also resulting in a $\mathrm{C}: \mathrm{H}$-ratio of 1:3 indicating $\mathrm{CH}_{3}$-groups. The much lower total amount of carbon and hydrogen in baking moulds compared to cyclic siloxanes indicates that there are highly branched siloxanes or methylized silica used as fillers.

Quantification of the ${ }^{1} \mathrm{H}-\mathrm{NMR}$ signals, as described in the "materials and methods" part, resulted in a composition of the overall migration of $89 \%$ cyclic dimethylsiloxanes and $6 \%$ MQ-resins related to the gravimetric result. According to Vincent (2000), a M:Q ratio of 0.9:1 was assumed for the calculation of the amount of MQ resins. About $5 \%$ of the migration residue remain unexplained. In consequence of the GC-, HPLC-, NMR- and elemental analysis it seems very unlikely that this part is made of organic compounds. We suppose inorganic filling materials, e.g. pyrogenic silicic acid or chemically modified (methylated) silica gel, which are often used for silicone elastomers (BfR 2007).

Since more than $90 \%$ of the migration residue consist of polysiloxanes, the amount of these determined by NMR can be a good approach for the determination of the overall migration. 
“[Insert Table II about here]"

\section{Validation of the ${ }^{1} H$-NMR quantification method}

No reference standards representing the migrating substances are commercially available so far. Cyclic silicones are only available up to hexamers $\left(D_{6}\right)$ which are much more volatile than the cyclic silicones up to $\mathrm{D}_{50}$ which we detected in the migrates investigated. Linear silicone oils (e.g. DMS-T07, DMS-T11) are available in higher molecular weight ranges but may exhibit a different mass distribution compared to the migrating silicones and result in additional ${ }^{1} \mathrm{H}-\mathrm{NMR}$ signals for terminal groups.

${ }^{1} \mathrm{H}-\mathrm{NMR}$-signals increase linearly with the number of the excited protons. In our studies, linearity was demonstrated in the range of $20-750 \mathrm{mg} \mathrm{kg}^{-1}$ fat $\left(7\right.$ levels in duplicate, $\mathrm{r}^{2}=$ 0.9975), using decamethylcyclopentasiloxane (D5) dissolved in sunflower oil as calibrant.

Determination of the most important validation parameters was based on nine baking experiments, each done as a threefold determination, in silicone muffin moulds using a common muffin recipe with a fat content of $21 \%$. The intra-day standard deviation $\left(\mathrm{s}_{\mathrm{r}}\right)$ of the method gave $0.92 \mathrm{mg}$ dimethylsiloxanes $\mathrm{kg}^{-1}$ food, which corresponds to a relative standard deviation of $7.3 \%$ (average overall migration of $12.8 \mathrm{mg} \mathrm{kg}^{-1}$ cake). For the uncertainty of measurement concerning the total migrate we have to take into account that the amount of dimethylsiloxanes determined by the ${ }^{1} \mathrm{H}-\mathrm{NMR}$ method recovers only $83-89 \%$ of the total migrate determined gravimetrically (see table II). All results obtained by the ${ }^{1} \mathrm{H}-\mathrm{NMR}$ method reported here only refer to the amount of dimethylsiloxanes without correction of the bias towards the gravimetry. The uncertainty of measurement for the reference method using olive oil or one of its substitutes given in Commission Directive 2002/72/EC is set up to 20 
$\mathrm{mg} \mathrm{kg}^{-1}\left(3 \mathrm{mg} \mathrm{dm}^{-2}\right)$. This is much higher than the sum of the estimated bias and the intra-day reproducibility. The limit of detection (quantification) was calculated based on the signal to noise ratio of 3 (9) at 8.7 (26.1) $\mathrm{mg} \mathrm{kg}^{-1}$ fat or 1.9 (5.7) $\mathrm{mg} \mathrm{kg}^{-1}$ cake. Because of the enrichment of siloxanes during the fat extraction step of the food, this relatively high detection limit is suitable to determine even low levels of siloxane contamination in food and is more than sufficient to prove the overall migration limit in fatty foodstuffs according to Resolution AP (2004) 5.

The recovery was determined as described in the materials and methods part. In an experiment performed in triplicate, a recovery rate of $(101.3 \pm 6.7) \%$ was reached for extraction of the oil and quantification of the siloxanes by ${ }^{1} \mathrm{H}-\mathrm{NMR}$. All validation parameters obtained are summarized in table 3.

"[Insert Table III about here]"

Commission Directive 2002/72/EC defines the analytical tolerance for the overall migration experiment into olive oil to $20 \mathrm{mg} \mathrm{kg}^{-1}$. Compared to this criteria the described ${ }^{1} \mathrm{H}-\mathrm{NMR}$ method is suitable for analysis of the overall migration from silicone baking moulds into food. Furthermore, the method allows one to examine overall migration from silicone moulds into real foodstuffs as well as into olive oil or its substitutes. The importance is that this approach now gives the possibility of checking compliance of silicone moulds with national law or the standards described in the Resolution AP (2004) 5 as well as enabling an exposure assessment for cyclic siloxanes in prepared foodstuffs to be carried out aiding in toxicological assessment.

\section{Siloxane migration into simulants and muffins}

The overall migration into olive oil and its substitutes isooctane, ethanol (95\%) and Tenax ${ }^{\circledR}$ were determined gravimetrically according to the rules set out in the migration directives (Council Directives 82/711/EEC and 85/572/EEC) from the first to the third experiment. The results are shown in figure 6. Isooctane, ethanol (95\%) and Tenax ${ }^{\circledR}$ are official substitutes for olive oil according to Council Directives 82/711/EEC and 85/572/EEC and therefore should give similar results. However, isooctane generated by far the highest migration giving $209 \mathrm{mg}$ $\mathrm{dm}^{-2}$ in the $1^{\text {st }}$ experiment, compared with ethanol which gave $25 \mathrm{mg} \mathrm{dm}^{-2}$ in the $3^{\text {rd }}$ experiment. In analogy to the rules for migration from plastic materials laid down in 
“[Insert figure 6 about here]"

The migration values were compared to the contamination of muffins baked in the same mould. The amounts of siloxanes detected in the muffins using ${ }^{1} \mathrm{H}-\mathrm{NMR}$ are given in table IV. As expected, we found much lower migration (about $10 \mathrm{mg} \mathrm{kg}^{-1}$ cake) compared to olive oil, due to the less lipophilic character and the texture of the muffin.

\section{"[Insert Table IV about here]"}

Migration was about $1 / 30$ and $1 / 8$ of the olive oil result for the $1^{\text {st }}$ and $3^{\text {rd }}$ experiment, respectively, demonstrating a completely different migration behaviour into the simulant compared with the food. Therefore, the applicability of the reduction factor of 5 according to Council Directive 85/572/EEC for bakery products is questionable. None of the simulants is suitable for imitating the migration processes in pastries. In a follow-up with 10 baking cycles, we surprisingly found the migration value to be almost constant (figure 7), indicating different migration kinetics compared to the liquid simulants as well as Tenax ${ }^{\circledR}$. Further experiments with two larger moulds confirmed a nearly constant migration from $1^{\text {st }}$ to $3^{\text {rd }}$ test but were not continued to the $10^{\text {th }}$ migration. More surprisingly, despite a quite different volume/surface ratio of the three compared moulds, all tested cakes contained similar siloxane amounts. More differences could be observed comparing migration values related to the surface of the moulds (table V). These almost similar migration values into creamed cake for moulds of different shape and size may result from a somewhat longer baking time needed in case of larger moulds and thus equalizing the more advantageous volume/surface ratio. 


\section{"[Insert Figure 7 about here]" \\ "[Insert Table V about here]"}

As a first conclusion, a single instead the $3^{\text {rd }}$ experiment, as claimed by law for the evaluation of plastics, could be sufficient to estimate the migration from silicone materials in muffins or cakes. Migration into cake does not differ strongly for moulds of various size making the use of small moulds as favourable as that of larger ones from the consumers point of view.

In addition, we proved the influence of the fat content in the dough using recipes with $21 \%$ and $30 \%$ fat. In both cases, again the results showed no significant difference between the $1^{\text {st }}$ and $3^{\text {rd }}$ migration for each fat content but gave a significantly higher migration for the muffins high in fat (figure 8). These results confirm the expected dependence of migration from the lipophilic character of the foodstuff and are therefore in good accordance with the literature (Forrest and Sidwell 2005). Muffins or plain cakes with much more than $30 \%$ fat are hardly to imagine, meaning it is unlikely that the overall migration limit will be exceeded when using silicone moulds for making a cake. Even without effective compliance control in the past, most of the silicone baking moulds placed on the market should meet the criteria of Resolution AP (2004) 5 and moreover of Article 3b of Regulation (EC) 1935/2004 prohibiting an unacceptable change of the composition of foodstuffs as long as they are used for baking pastries.

\section{"[Insert Figure 8 about here]"}

It has to be outlined that there is hardly any obvious correlation between the migration data for simulants, even when data are corrected by the reduction factor which has to be applied for cake, and the amount of siloxanes found in cake, neither for the mid nor for the high fat cake. The migration kinetics as well as the amount of migrating substances differ strongly due to the less lipophilic character and the texture of the cake. In conclusion, since the requirements of article 3 of Regulation (EC) No 1935/2004 refer to food and not to simulants and there is to date no adequate testing procedure warranting comparable results between food and simulants it is mandatory to prove compliance only with food. 


\section{Conclusion}

The method presented here is the first fully validated method to investigate the overall migration of silicone baking moulds into olive oil, substitutes and foodstuffs and therefore provides an essential tool to check the legal compliance of silicone moulds already placed on the market. No other suitable and validated method has so far been published.

Investigating the migration properties of silicone elastomers using gravimetric and ${ }^{1} \mathrm{H}-\mathrm{NMR}$ analysis resulted in very different data depending on the food, simulant or substitute used. Based on our data, it has to be concluded that the migration test with olive oil, as required by Council Directive 82/711/EEC, does not give a realistic scenario of the migration into cake, even when the official reduction factor is used. This concerns the amount of migration as well as variations from $1^{\text {st }}$ to $3^{\text {rd }}$ migration test. There are also big differences between the migration data for olive oil and its substitutes ethanol (95\%), isooctane and Tenax $®$ according to Directive 82/711/EEC. Neither the liquid solvents nor Tenax® give similar results to olive oil as easily to expect but presupposed by the migration directives.

Consequently, the olive oil test may act only as a convention in the sense of an inertness parameter for the investigated material. It seems more appropriate to search for a simpler and better reproducible test method for silicone elastomer materials. Based on our results we suggest the much easier and more precise extraction procedure with ethanol (95\%) and to focus on the $1^{\text {st }}$ extract only (with a therefore new defined limit for the total extractives in ethanol). This follows the same consideration as German BfR recommendation XV (BfR 2005) in which limits for both volatile and extractable substances have been defined, but not a migration limit. 
To judge a silicone article with regard to the requirements of article 3 of Regulation (EC) No 1935/2004 migration testing has to be done in food absolutely. This recognition well confirms with other findings proving migration into food to be sometimes completely different compared to migration into simulants as described for isopropylthioxanthone (BfR 2006), plasticizers in gaskets (Fankhauser-Noti 2006) and other (Foodmigrosure 2007).

The discussed ${ }^{1} \mathrm{H}-\mathrm{NMR}-\mathrm{method}$ is suitable for examining the legal compliance of silicone articles in food contact as well as for a reliable exposure assessment of consumers. Preparing cake in a silicone mould usually will not result in exceeding the overall migration limit of 60 $\mathrm{mg} \mathrm{kg}^{-1}$ or in a relevant contamination of the foodstuff from the toxicological point of view. Actual investigations of our research group indicate a much higher amount of migrating siloxanes for silicone moulds used for the preparation of meat loafs, even exceeding the overall migration limit. Further experiments are currently in preparation.

\section{Acknowledgment}

The authors would like to thank the Wacker Co. (Burghausen, Germany) for financial support of the studies. We also gratefully acknowledge Dr. Margit Gruner and Annett Rudolph (Technical University of Dresden, Institute of Organic Chemistry) for doing numerous NMR measurements and Dr. Uwe Schwarzenbolz (Technical University of Dresden, Chair of Food Chemistry) for doing the LC-MS measurements.

\section{References}

BfR - Federal Institute for Risk Assessment, Germany. Plastics Committee. $120^{\text {th }}$ meeting, 22/23 November 2006. Available from:

http://www.bfr.bund.de/cm/207/120_sitzung_der_vorlaeufigen_kunststoffkommission_des_bf r.pdf. Accessed 2008, April 25.

BfR - Federal Institute for Risk Assessment, Germany. Recommendation XV on silicone articles. 2007 June 01. Available from:

http://bfr.zadi.de/SEARCH/BASIS/kse1/all/blob_dt/DDD/150DEUTSCH.pdf. Accessed 2008, April 25. 
BfR - Federal Institute for Risk Assessment, Germany. Druckfarben in Lebensmitteln Bewertung des Verbraucherrisikos wegen fehlender Daten nicht möglich. 2006 January 30. Available from:

http://www.bfr.bund.de/cm/216/druckfarben_in_lebensmitteln_bewertung_des_verbraucherris ikos_wegen_fehlender_daten_nicht_moeglich.pdf. Accessed 2008, July 17.

Biggs RB, Fetzer JC, Brown RJ. 1987. Determination of Silicon Compounds by Gradient Liquid Chromatographic Separation with Direct Current Plasma Atomic Emission Spectrometric Detection. Anal. Chem. 59. 2798-2802

Čavić-Vlasak BA, Thomson M, Smith DC. 1996. Silicones and their determination in biological matrices. A review. Analyst 121.53R-63R

CEN Standards EN 1186. Materials and articles in contact with foodstuffs. Plastics. Part 1-14. December 2002

Commission Directive 90/128/EEC of 23 February 1990 relating to plastic materials and articles intended to come into contact with foodstuffs. Official Journal of the European Communities, L 75, 1990 March 21, p. 19-40

Commission Directive 2001/62/EC of 9 August 2001 amending Directive 90/128/EEC relating to plastic materials and articles intended to come into contact with foodstuffs. Official Journal of the European Communities, L 221, 2001 August 17, p. 18-36

Commission Directive 2002/72/EC of 6 August 2002 relating to plastic materials and articles intended to come into contact with foodstuffs. Official Journal of the European Communities, L 220, 2002 August 15, p. 18-58

Council Directive 82/711/EEC of 18 October 1982 laying down the basic rules necessary for testing migration of the constituents of plastic materials and articles intended to come into contact with foodstuffs. Official Journal of the European Communities, L 297, 1982 October 23, p. $26-30$

Council Directive 85/572/EEC of 19 December 1985 laying down the list of simulants to be used for testing migration of constituents of plastic materials and articles intended to come 
into contact with foodstuffs. Official Journal of the European Communities, L 372, 1985

December 315, p. 14-21

Council Directive 89/107/EEC of 21 December 1988 on the approximation of the laws of the Member States concerning food additives authorized for use in foodstuffs intended for human consumption. Official Journal of the European Communities, L 40, 1989 February 11, p. 2733

Dorn SB, Skelly Frame EM. 1994. Development of a high-performance liquid chromatographic-inductively coupled plasma method for speciation and quantification of silicones: From silanols to polysiloxanes. Analyst 119. 1687-1694

Fankhauser-Noti A, Grob K. 2006. Migration of plasticizers from plastisol gaskets of lids for glass jars into oily foods: amount of gasket material in food contact, proportion of plasticizer migrating into food and compliance testing by simulation. Trends in Food Science \& Technology 17. 105-112

Food Migrosure project. Modelling Migration from plastics into foodstuffs as a novel and cost efficient tool for estimation of consumer exposure from food contact material.

Available from:

http://www.foodmigrosure.com/. Accessed 2008, July 17.

Forrest MJ, Holding SR, Howells D, Eardley M. 2006. The use of GCxGCTOFMS and LC-MS for the determination of migrants from silicone rubbers into food simulants and food products. Silicone Elastomers, 19-20 September 2006, Frankfurt Germany (oral contribution)

Forrest MJ, Sidwell J. 2005. Chemical migration from silicones used in connection with food contact materials and articles (Food Standard Agency Contract Number A03046)

GFK Panel Services Germany [internet]. Available from:

http://www.gfk.com/imperia/md/content/ps_de/chart_der_woche/kw49_06_silikonbackforme n.pdf. Accessed 2007, April 15. 
Kala SV, Lykissa ED, Lebovitz RM. 1997. Detection and characterization of poly(dimethyl)siloxanes in biological tissues by GC/AED and GC/MS. Anal. Chem. 69. $1267-1272$

Kennan JJ, McCann Breen LL, Lane TH, Taylor RB. 1999. Methods for Detecting Silicones in Biological Matrixes. Anal. Chem. 71. 3054-3060

Kim HJ; Kim SH, Lee CH, Nah J-W, Hahn A. 2003. DEHP Migration Behavior from Excessively Plasticized PVC Sheets. Bull Korean Chem. Soc. 24/3. 345-349

Mccamey DA, Iannelli DP, Bryson LJ and Thorpe TM. 1986. Determination of silicone in fats and oils by electrothermal atomic absorption spectrometry with in-furnace air oxidation. Analytica chimica acta 188. 119-126

Meister Verlag (Ed.) 1999. Backen und Genießen. Munich: Meister Verlag

Meuwly R, Brunner K, Fragnière C, Sager F, Dudler V. 2005. Heat stability and migration from silicone baking moulds. Mitt. Lebensm. Hyg. 96. 281-297

Mojsiewicz-Pieńkowska K, Jamrógiewicz Z, Łukasiak J. 2003. Determination of polydimethylsiloxanes by ${ }^{1} \mathrm{H}-\mathrm{NMR}$ in wine and edible oils. Food Additives and Contaminants 20. $438-444$

Peters W, Smith D, Lugowski S, McHugh A, Baines C. 1995. Do patients with silicone-gel breast implants have elevated levels of blood silicon compared with control patients? Annals of Plastic Surgery 34. 343-347

Rapid Alert System for Food and Feed (RASFF). Notification 2007.0557 from 2007-08-16. Available from: http://ec.europa.eu/food/food/rapidalert/index_en.htm. Accessed 2008, May 06.

Regulation (EC) No 1935/2004 of the European Parliament and of the Council of 27 October 2004 on materials and articles intended to come into contact with food and repealing 
Directives 80/590/EEC and 89/109/EEC. Official Journal of the European Communities, L 338, 2004 November 13, p. 4-17

Resolution AP (2004) 5 on silicones used for food contact applications. Council of Europe. Public Health Committee. Committee of experts on materials coming into contact with food. 2004 June 10. Available from:

http://www.coe.int/t/e/social_cohesion/soc\%2Dsp/public_health/food_contact/Resolution\%20 AP\%20_2004_\%205\%20on\%20silicones.pdf. Accessed 2007, November 22.

Synoptic Document. Provisional list of monomers and additives notified to European Commission as substances which may be used in the manufacture of plastics or coatings intended to come into contact with foodstuffs. SANCO D3/AS D (2005). Version from 2005 July 25. Available from:

http://ec.europa.eu/food/food/chemicalsafety/foodcontact/synoptic_doc_en.pdf. Accessed 2008, May 30.

Verlag für die Frau (Ed.) 1967. Das Backbuch. $1^{\text {st }}$ edition. Leipzig: Verlag für die Frau Verordnung des EDI vom 23. November 2005 über Bedarfsgegenstände, Stand 1. April 2008 (SR 817.023.21). Available from: http://www.admin.ch/ch/d/sr/c817_023_21.html. Accessed 2008, May 06.

Vincent GA, Tonge JS. 2000. Methods of making alkoxylated resin-polymer organosilicone networks and products obtainable therefrom. Eur. Pat. Appl. EP 1083195 A1 


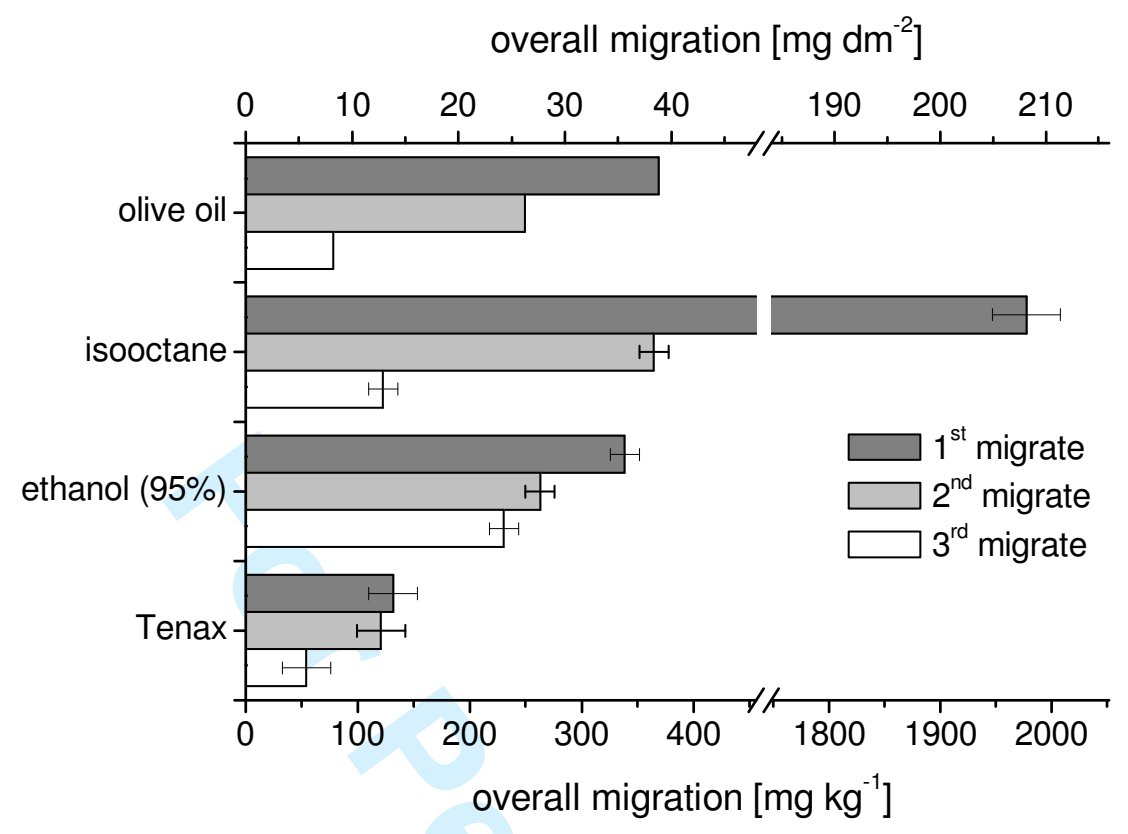

Figure 6. Overall migration into simulants (after gravimetric determination according to EN 1186:2002). Data shown: mean \pm confidence interval $(\alpha=0.05)$, threefold determination (olive oil: single determination). 


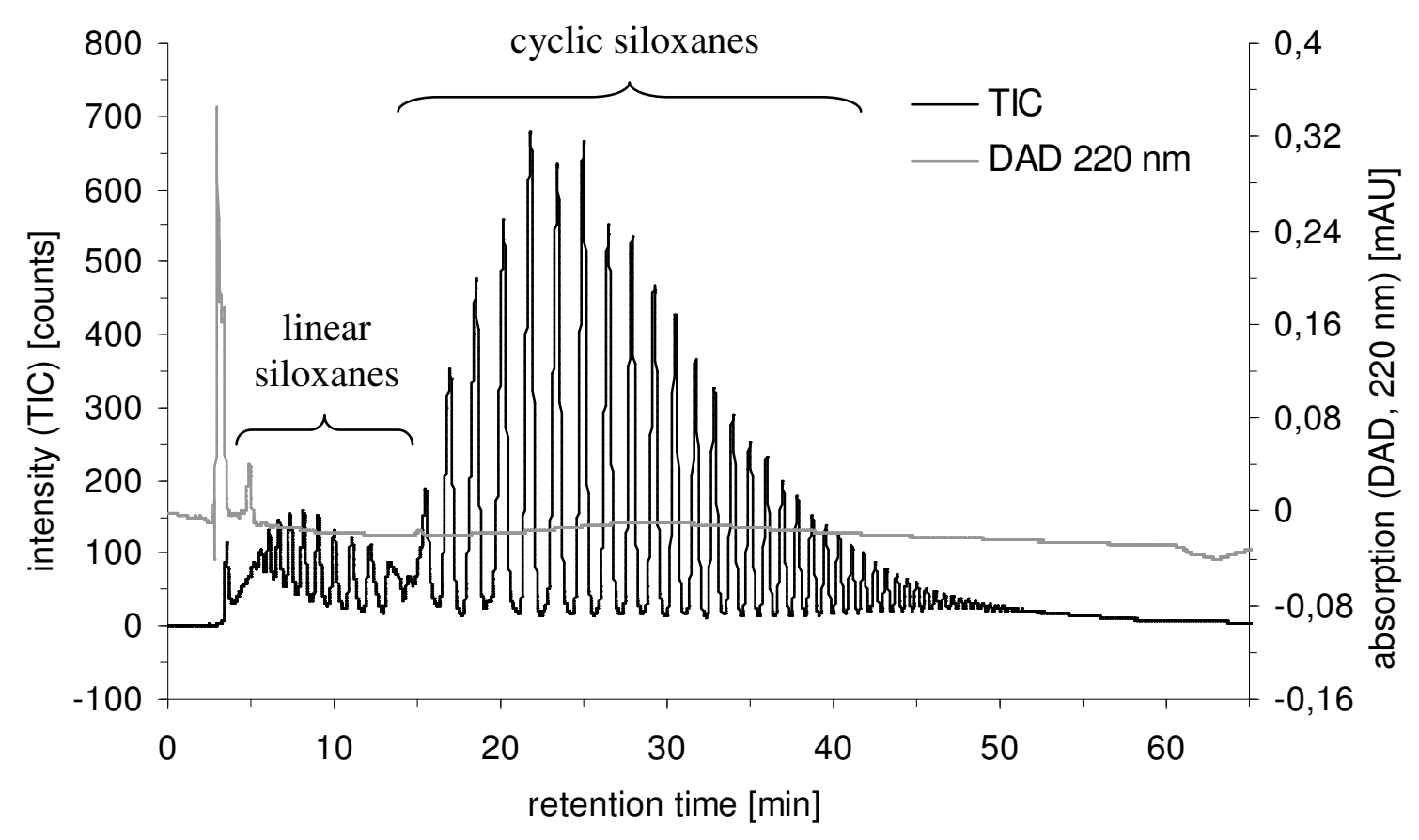

Figure 3. RP-HPLC-MS/DAD chromatogram of the migration residue from a silicone baking mould containing hydroxyl terminated dimethylsiloxanes $(\mathrm{m} / \mathrm{z} 300-4000)$ 


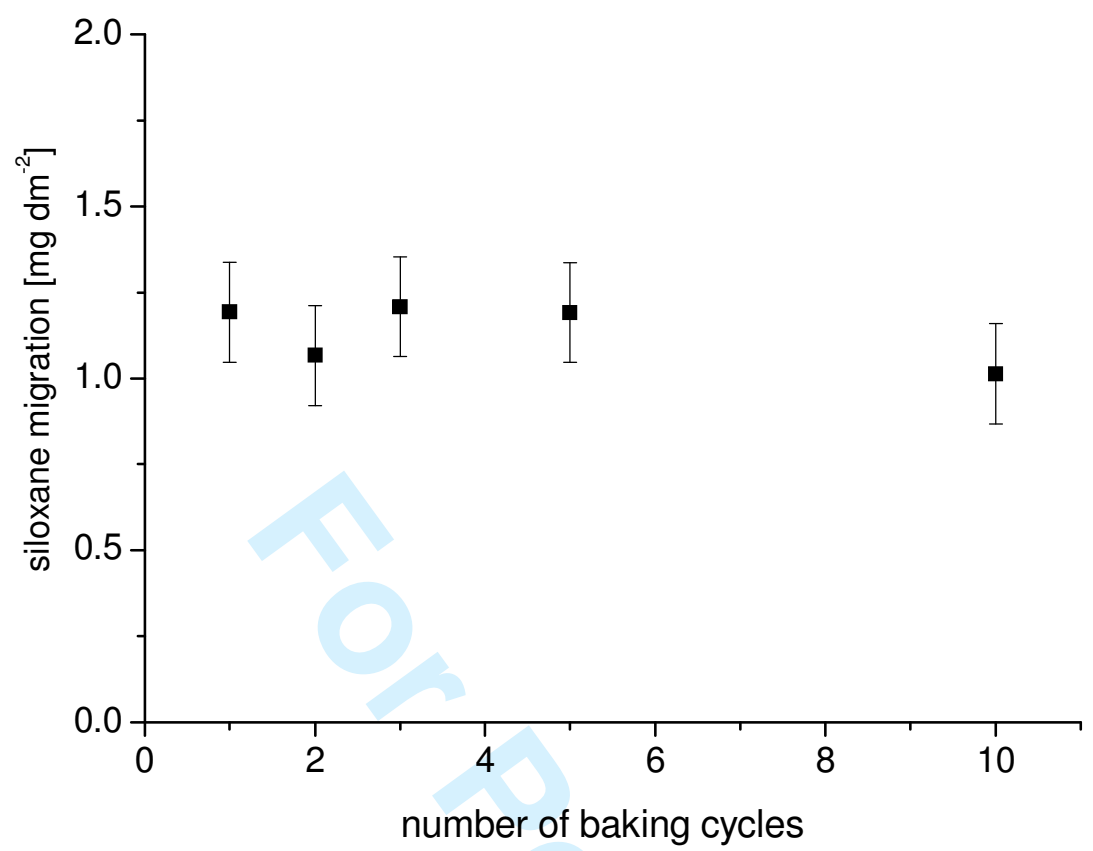

Figure 7. Siloxane migration into creamed cake during repeated usage. Data shown: mean \pm confidence interval $(\alpha=0.05)$, threefold determination. 
Abundance

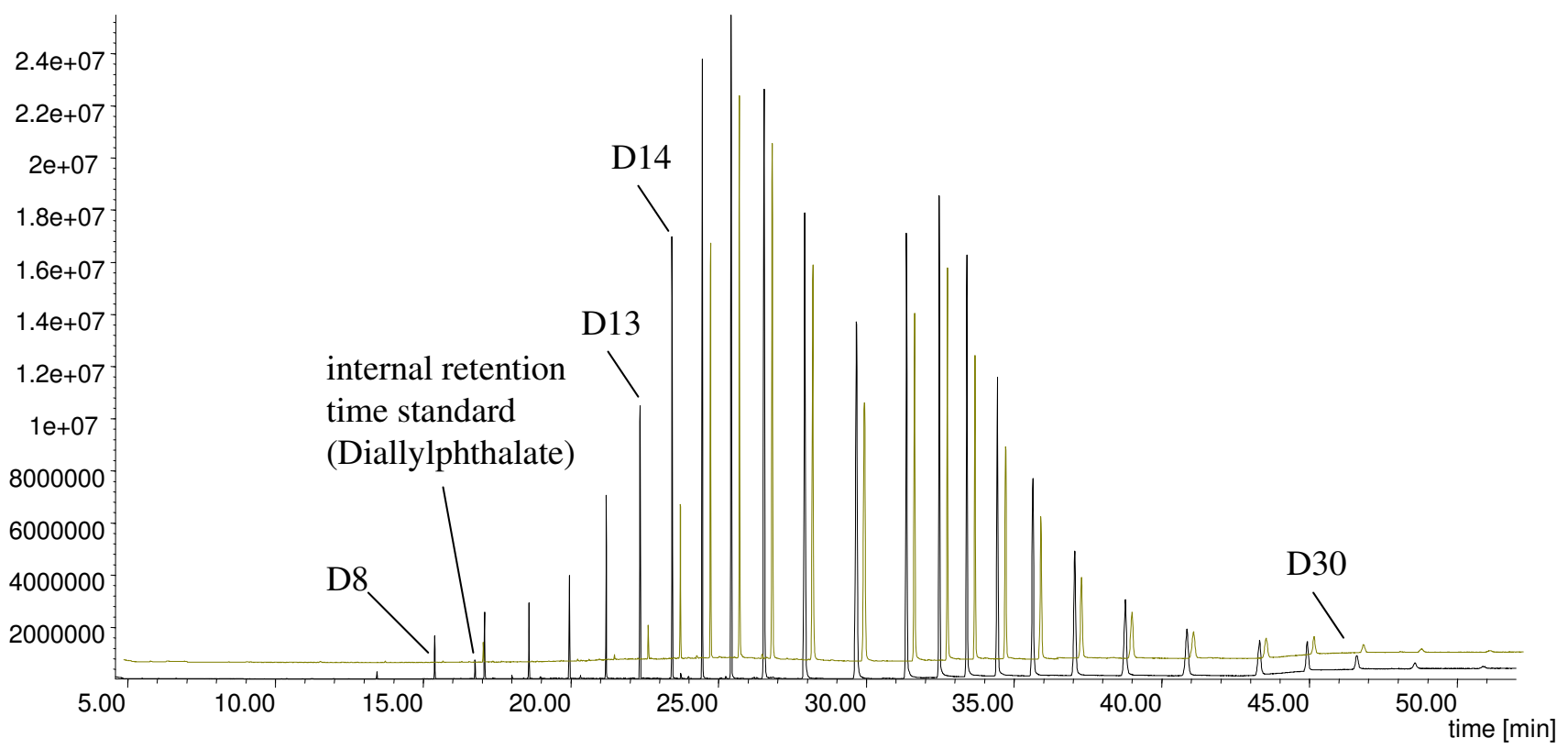

Figure 4. GC-MS chromatogram (m/z 65-800) of the ethanol extracts of 2 different moulds with oligomers from D8 - D32 or D 13 - D 32 respectively. Differences in the amount of low molecular weight oligomers may be caused by the process of preheating (tempering).

GC-parameters: Injection splitless at $280^{\circ} \mathrm{C}$, oven temperature starting at $50^{\circ} \mathrm{C}$ and rising up to $360^{\circ}$ C. Column HP-5MS. 
Figure 8. Comparison of the overall migration into creamed cake (determination via ${ }^{1} \mathrm{H}$ NMR) and food simulants (gravimetric determination according to EN 1186:2002). Reduction factor $\mathrm{x} / 5$ (Council Directive 85/572/EEC) is regarded (in contrast to Fig. 6) . Data shown: mean \pm confidence interval $(\alpha=0.05)$, threefold determination (olive oil: single determination). 
Figure 5. ${ }^{1} \mathrm{H}$-NMR spectrum of the migration residue 
Table I. Determination of the average molar mass of triglycerides from the ${ }^{1} \mathrm{H}-\mathrm{NMR}$ spectrum of the lipid matrix $\left(\mathrm{M}_{\mathrm{SU}}\right.$ : molar mass of the subunit $\left[\mathrm{g} \mathrm{mol}^{-1}\right]$; $\mathrm{I}$ : integral of the signal(s) in the ${ }^{1} \mathrm{H}-\mathrm{NMR}$ spectra; p: number of protons responsible for the ${ }^{1} \mathrm{H}-\mathrm{NMR}$ signal; $\mathrm{I} / \mathrm{p}$ : amount of substance ratio; $\mathrm{SU}$ : subunit of the triglyceride molecule; $\mathrm{TB}: \mathrm{CH}_{2} \mathrm{O}-\mathrm{CO}$ unit at the triglyceride backbone)

\begin{tabular}{|c|c|c|c|c|c|c|}
\hline signal & subunit & $\mathrm{M}_{\mathrm{SU}}\left[\mathrm{g} \mathrm{mol}^{-1}\right]$ & $\mathbf{I}^{\mathbf{a}}$ & $\mathbf{p}$ & $\mathbf{I} / \mathbf{p}$ & $\frac{\left(\mathrm{I} \cdot \mathrm{p}^{-1}\right)_{\mathrm{SU}}}{\left(\mathrm{I} \cdot \mathrm{p}^{-1}\right)_{\mathrm{TB}}} \cdot 2^{\mathrm{c}}$ \\
\hline 1 & $\mathrm{CH}_{3}$ (fatty acids) & 15,03 & 218,1 & 3 & 72,7 & 2,9 \\
\hline $2-6$ & $\mathrm{CH}_{2}$ (fatty acids) & 14,03 & 1912,4 & 2 & 956,2 & 38,2 \\
\hline 7 & $\begin{array}{c}\mathrm{CH}_{2} \mathrm{O}-\mathrm{CO} \text { (triglyceride } \\
\text { backbone) }\end{array}$ & 58,04 & 100,0 & 2 & 50 & $2^{\mathrm{b}}$ \\
\hline $8-9$ & $\mathrm{CH}$ & 13,02 & 254,1 & 1 & 254,1 & 10,2 \\
\hline & $\begin{array}{c}\mathrm{COO} \\
\text { (C2 of the triglyceride } \\
\text { backbone) }\end{array}$ & 44,01 & - & - & - & $1^{\mathrm{b}}$ \\
\hline
\end{tabular}

\footnotetext{
${ }^{a}$ The integral of signal 7 is set up to 100,0 .

${ }^{\mathrm{b}}$ Each triglyceride molecule contains two $\mathrm{RCH}_{2} \mathrm{O}-\mathrm{CO}$ units (at $\mathrm{C} 1$ and $\mathrm{C} 3$ of the triglyceride backbone) and one $\mathrm{R}_{2} \mathrm{CHO}-\mathrm{COO}$ unit (at $\mathrm{C} 2$ of the triglyceride backbone).

${ }^{\mathrm{c}}$ factor 2 regarding that each triglyceride molecule contains two $\mathrm{CH}_{2} \mathrm{O}-\mathrm{CO}$ units
} 
Table III. Analytical parameters of the ${ }^{1} \mathrm{H}-\mathrm{NMR}$ determination of dimethylsiloxanes in pastries (data refer to a creamed cake with $21 \%$ fat in the dough and are given mass related to avoid the uncertainty of surface calculation).

\begin{tabular}{llc}
\hline calibrated range & {$\left[\mathrm{mg} \mathrm{kg}^{-1}\right.$ triglyceride $]$} & $20-750$ \\
& {$\left[\mathrm{mg} \mathrm{kg}^{-1}\right.$ cake $]$} & $5-170$ \\
coefficient of determination $\left(\mathbf{r}^{2}\right)$ & & 0.9975 \\
\hline recovery rate & {$[\%]$} & $101.3 \pm 6.7 *$ \\
\hline & & 7.3 \\
\hline relative standard deviation $(\mathbf{R S D})$ & {$[\%]$} & 4,2 \\
\hline standard deviation (intra day, $\left.\mathbf{s}_{\mathbf{r}}\right)$ & {$\left[\mathrm{mg} \mathrm{kg}^{-1}\right.$ triglyceride $]$} & 0.92 \\
\cline { 2 - 3 } & {$\left[\mathrm{mg} \mathrm{kg}^{-1}\right.$ cake] } & 8.7 \\
\hline limit of detection $(\mathbf{L O D})$ & {$\left[\mathrm{mg} \mathrm{kg}^{-1}\right.$ triglyceride $]$} & 1.9 \\
$(\mathrm{~S} / \mathrm{N}=3)$ & {$\left[\mathrm{mg} \mathrm{kg}^{-1}\right.$ cake $]$} & 26.1 \\
\hline limit of quantification $(\mathbf{L O Q})$ & {$\left[\mathrm{mg} \mathrm{kg}^{-1}\right.$ triglyceride $]$} & 5.7 \\
$(\mathrm{~S} / \mathrm{N}=9)$ & {$\left[\mathrm{mg} \mathrm{kg}^{-1}\right.$ cake] } & \\
\hline
\end{tabular}

*mean \pm confidence interval $(\alpha=0.05$, threefold determination) 
Table IV. Overall migration into creamed cake (21\% fat in the dough) (test conditions: 25 min, $175^{\circ} \mathrm{C}$ ), determined by ${ }^{1} \mathrm{H}-\mathrm{NMR}$. Data shown: mean (threefold determination). Confidence interval $(\alpha=0.05): 0.15 \mathrm{mg} \mathrm{dm}^{-2}\left(1.00 \mathrm{mg} \mathrm{kg}^{-1}\right)$ based on standard deviation $\mathrm{s}$ of the procedure: $\mathrm{s}=0.11 \mathrm{mg} \mathrm{dm}^{-2}\left(0.92 \mathrm{mg} \mathrm{kg}^{-1}\right)$

\begin{tabular}{ccc}
\hline & \multicolumn{2}{c}{ siloxane migration } \\
\cline { 2 - 3 } Migrate & {$\left[\mathbf{m g ~ d m}^{-2}\right]$} & {$\left[\mathbf{m g ~ k g}^{-1}\right]$} \\
\hline $1^{\text {st }}$ & 1.19 & 10.00 \\
$2^{\text {nd }}$ & 1.07 & 8.94 \\
$3^{\text {rd }}$ & 1.21 & 10.11 \\
$5^{\text {th }}$ & 1.19 & 9.98 \\
$1^{\text {th }}$ & 1.01 & 8.46 \\
\hline
\end{tabular}




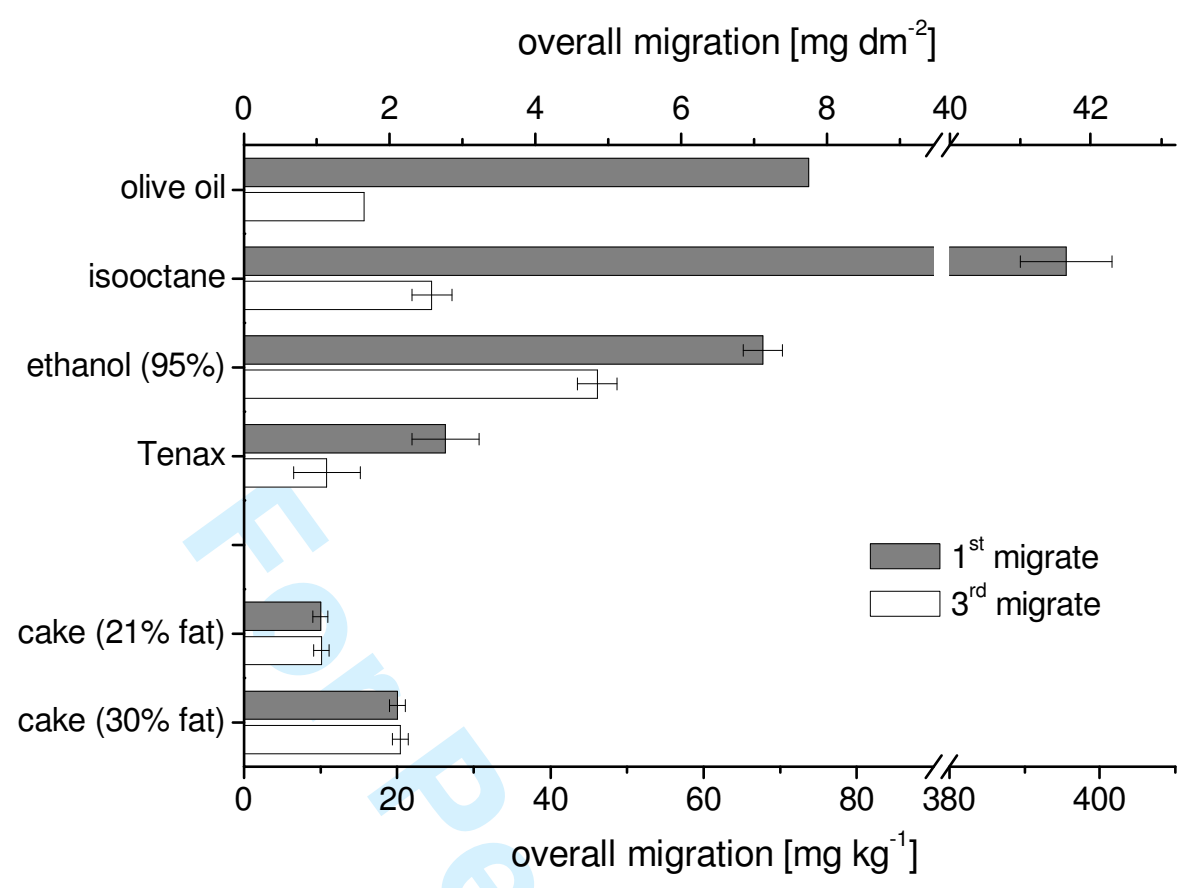

Figure 8. Comparison of the overall migration into creamed cake (determination via ${ }^{1} \mathrm{H}$ NMR) and food simulants (gravimetric determination according to EN 1186:2002). Reduction factor $\mathrm{x} / 5$ (Council Directive 85/572/EEC) is regarded (in contrast to Fig. 6) . Data shown: mean \pm confidence interval $(\alpha=0.05)$, threefold determination (olive oil: single determination). 